\title{
Sexual selection and the evolution of beauty: two views
}

\author{
Egbert Giles Leigh Jr
}

\section{Abstract}

This is a review of Ryan's A Taste for the Beautiful and Prum's The Evolution of Beauty, two books that show how sexual selection by female choice can favor the evolution of beauty.

\section{Book details}

A Taste for the Beautiful: The Evolution of Attraction, by Michael J. Ryan.

Princeton NJ: Princeton University Press. 2018. pp. $\mathrm{x}+200$. ISBN 978-0-691-16726-8. H/b \$27.95.

The Evolution of Beauty: How Darwin's Forgotten Theory Shapes the Animal World-and Us, by Richard O. Prum.

New York: Doubleday. 2017. pp. xii +429. ISBN 978-0385-53721-6. H/b \$30.00.

New York: Anchor Books. 2018. pp. xiv +428 . ISBN 978-0-345-80457-0. S/b \$17.00.

\section{Book Review}

Sexual selection occurs when animals of one sex compete to mate with members of the other. Members of one sex (usually males) may fight each other for the privilege of mating with members of the other, as in deer or sea lions. In many other species, such as peacocks, males compete to attract mates by beauty of appearance or behavior, leaving females free to choose whom to mate with, a process called female choice (Darwin 1871; Fisher 1930). Darwin developed the concept of sexual selection because he realized that natural selection could not explain the evolution of a male peacock's array of long tail-feathers which, despite its beauty, almost annihilates its possessor's ability to escape from predators (Darwin 1871, vo1. 2, p. 97). Both books reviewed here focus on sexual selection by female choice: how males of different species compete to persuade females to choose them

*Correspondence: bufotyphonius@gmail.com Smithsonian Tropical Research Institute, Panama City, Panama as mates, what criteria females use to choose, and how their choices affect evolution. These books will interest this Journal's readers because they suggest that evolution is not a purely utilitarian process: females often favor the evolution of beauty for its own sake, choosing males for their beauty in form, color and behavioral displays, characteristics which may, like Hardy's (1967, pp. 101, 119$120,150)$ number theory, be of no practical use whatever.

Darwin (1871, p. 257) distinguished non-adaptive sexual from adaptive natural selection very carefully, remarking that sexual selection applies to characteristics which "serve only to give one male an advantage over another" although "the less well-endowed males, if time were allowed them... (would) pair with the females; and they would, in all other respects... be equally well adapted for their ordinary habits of life. In such cases sexual selection must have come into play, for the males have acquired their present structures, not from being better fitted to survive in the struggle for existence, but from having gained an advantage over other males." In other words, Darwin defined sexual selection as a process which did not enhance adaptation. This fact seems almost unknown to evolutionary biologists, too few of whom have read Darwin (1871) with sufficient attention.

Sexual selection was largely ignored for the first hundred years after Darwin (1871), because it seemed irrelevant to the battle to vindicate natural selection on variation arising without regard to its bearers' needs as a viable cause of adaptation. Competition among males for females seemed an obvious aspect of the struggle for existence. If considered at all, female choice was invoked as an engine of adaptation, as (it was assumed) they would choose to mate with the best adapted males. 
This attitude was too utilitarian for any to consider how beauty evolved. Biologists, moreover, were not subtle enough to see that genetic systems must be specifically adapted to make natural selection favor adaptive evolution. Williams (1966, p. 27) considered segregation distortion-biasing meiosis in heterozygotes in one's own favor-as just another way an allele could acquire selective advantage. In fact, fair, unbiased meiosis is needed to ensure adaptive evolution (Leigh 1991) because this suppresses conflicts between the advantage of particular alleles and the common interest of the autosomal genes. As we shall see, sexual selection by female choice bears on both themes, the evolution of beauty, and resolving conflicts between individual advantage and the good of the group.

I first discuss Ryan's book, a balanced, comprehensive account of the bases of male attractiveness and female choice. Working with tungara frogs in Panama, he was first to document decisive influence of female choice on male mating success in the wild (Ryan 1980). $\mathrm{He}$ and his students have studied in detail the bases of and influences on sexual selection in these frogs (Ryan, chapter 2), revealing a marvelously complex story. A tungara frog's call is either a simple whine (as in all calls of other species of its genus), or a whine followed by one or more chucks. The whine is species-specific, and the "amphibian papilla" in a tungara's ear is tuned to be most responsive to whines of its own species. A tungara female placed between two speakers, one broadcasting only whines, the other, whines followed by chucks, is six times more likely to approach the speaker broadcasting whines with chucks. Whines with chucks also cause auditory nerves to send stronger signals to the brain. Although supplementing whines with attractive chucks costs little extra energy, males are reluctant to add chucks, which attract predatory bats that eat male frogs when they aggregate to call for mates. Females also prefer deeper chucks, which larger males, more likely to fertilize all their eggs, make-because they hear them better! Ears of all species of this genus of frog have a "basal papilla," tuned to $2200 \mathrm{~Hz}$, even though only tungara frogs add chucks (averaging $2500 \mathrm{~Hz}$ ) to their whines. Since the basal papilla is tuned to $2200 \mathrm{~Hz}$, females can hear deeper, lower-frequency chucks more easily. Ryan's discovery illustrates his care: many would have concluded that females choose larger males with deeper chucks because they fertilize more eggs, and stopped the study. Finally, females in other species whose males never make chucks are more attracted to synthetic calls with chucks added to the whines of their species. Chucks thus exploited a pre-existing preference rather than coevolving with female preference for them. These conclusions are based on natural history, simple choice experiments, and studies of ear physiology and auditory nerve activity.

Ryan next discusses constraints on, and general features of, sexual selection. The range of an animal's sensory abilities is limited by the data-processing capacity of its brain, and its array of sensory abilities, which is shaped by what it needs to know to find food and escape predators. Thus nocturnal bats depend more on echolocation and smell than vision for navigating and finding food. Moreover, animals respond to proportional differences in signal strength (Weber's law): a tungara female that easily distinguishes between a one-chuck and a twochuck call hears little difference between six- and sevenchuck calls. These factors all affect a female's response to a male's courtship signals. A female often integrates various stimuli in choosing a mate. The stimulus that causes a Drosophila female to respond to a courting male is the odor of a specific male pheromone, but the sound of the male's stylized wing-buzzing, the sight of his athletic dancing, and his taste (courting males do a lot of groping, tasting with their legs) influence her decision to mate (Ryan, pp. 38-39). Ryan discusses the molecular mechanisms behind a female Drosophila's preference for a particular odor and a particular taste.

A female's first priority is choosing a mate of her species. Thus, in the tungara genus, female brains and ears are tuned to respond only to whines of males of their species. Some males, however, may more closely match the female's criteria of being in her species, so they appear more attractive (beautiful?) to her, even if they enhance her reproduction no more than their fellows would. Here, sexual selection is purely aesthetic. Moreover, some female aesthetic preferences seem utterly unrelated to a male's quality as a mate (whether he enables her to produce more or better offspring). Just as a female frog in species which never make chucks prefers synthetic calls where chucks are added to whines of her species, so a female platyfish in a species whose males lack sword-like tails prefers males of her species to whom the experimenter has added a sword-like tail (Ryan, pp. 41-42). A female does benefit by choosing a "quality" mate that enables her to have more or better offspring. Quality may reflect better health, better condition, or better genes. Thus calls of male tungara frogs infected by the potentially lethal chytrid fungus, which could infect his mates, are far less attractive than those of normal males (Ryan, p. 79). But she rarely practices eugenics. Ryan's third chapter is based primarily on birds, fish and frogs. These are easier to study experimentally, but their responses to sexual stimuli may be governed more often by fixed motor patterns (Lorenz 1977, pp. 55-57).

Next, Ryan discusses the roles of vision, hearing and smell on sexual selection-in decreasing order of ability 
to localize the signal's source and increasing order of the distance the signal can carry. Visual sexual beauty is analogous to a skilled artist's painting in that, as an artist seeks to grip the viewer with his own emotional response to a scene (Changeux 2012, p. 39), so the beauty in appearance or performance of a courting male is adapted to grip females with a desire to mate with him. As symmetry plays a subtle but often vital role in human art, in many species, including human beings, females prefer males of more symmetrical form (Ryan, pp. 66, 74-75). Color vision originally evolved to enhance foraging effectiveness, but males of many species, like quetzals and birds of paradise, deploy color to enhance their beauty. What colors best attract females, however, depends on the light conditions prevailing where males of the species court (Ryan, pp. 60-61). In some species, such as bowerbirds, males build structures to enhance their attractiveness. Bowerbirds of a few species build impressively large, well-constructed huts with piles of brightly colored objects placed in specific parts of the forecourt. Finally, some males would prefer mates with unachievable properties. Female fritillary butterflies attract males by flapping their wings: the faster they flap, the more attractive they are. A sped-up movie showing a female flapping her wings ten times faster than is energetically possible is, however, even more attractive (Ryan, p. 62).

Most frogs, grasshoppers, crickets, cicadas and katydids, and many birds, use sound as a primary means of calling, and arousing sexual desire in, potential mates. These calls allow females to identify males of their own species. Frog calls and nocturnal insect sounds, however, also attract predators and parasites, which can severely limit calling. Indeed, a male Asian corn borer moth mates with a female by mimicking the "terminal buzz" of a bat catching an insect, freezing her in such fear that she cannot resist mating with him (Ryan, pp. 93-94). As with color, different sounds communicate best in different habitats, so grassland birds' calls have higher frequencies and faster pulse rates than forest birds' calls (Ryan, p. 86). Although a male tungara frog can keep making the same call again and again without boring the female, a nightingale or song sparrow must vary his song to keep a female interested. A nightingale may have a repertoire of 150 songs (Ryan, p. 87). Healthier song sparrows have larger song repertoires (Ryan, pp. 88-89). Finally, a male must make himself heard above the multitude of his fellow callers. Some amplify their calls by calling from burrows or cavities whose length matches the call's wavelength. Experiment showed that a certain frog in a cavity partly filled with water matched the wavelength of his call to the length of the unfilled part of his cavity. When some of the water was removed, the frog increased the wavelength of his call to match the enlargement of the unfilled part of his cavity (Ryan, p. 97).

Olfactory receptors are usually neurons, so odor is communicated more directly to the brain than other sensory modes. Perfume has a notorious impact on some men. Many animals, such as fruit-eating bats, Drosophila, and nectar-eating moths find food by smell: Drosophila and moths also use odor to attract mates. Male moths have separate sensors on their antennae for flower scents vs the pheromone females of their species use to attract mates (Ryan, p. 110). The pheromone is a species-specific mixture of two chemicals. Males can be very sensitive to their females' pheromone: the French insect behaviorist Fabre (1916) tells how a large female moth emerged from her cocoon in his house, ready to mate, and filled it with the males she attracted. He rarely caught this species otherwise. Drosophila court on rotting fruit, where females lay eggs, so the smell of such fruit also excites sexual interest (Ryan, p. 111). Finally, a rodent's odor reflects the genetics of its primary immunity locus (MHC). Mating with an individual with different $\mathrm{MHC}$ genes yields healthier young, and odor allows these rodents (and human beings?) to choose mates with different MHC genes (Ryan, p. 118).

Ryan then discusses factors which makes a female's sexual responsiveness vary in time: ovulation time, and age (as menopause approaches, a woman is more anxious to reproduce). In many promiscuous species, females are more likely to mate with a male when they see others choose him (Ryan, p. 135). He ends by discussing how male traits and female preferences can evolve to match. First, selection favors those females that choose mates that best enhance their reproductive success. These mates must be of her species and should be more fertile, healthier, and often, more likely to provide resources benefiting their offspring. Color is often a good index of health, so selection often favors females that choose brighter-colored mates. Health is one thing, but Ryan finds little evidence that females evolve to prefer males that provide their young with better genes (Ryan, p. 151). Another possibility is coevolution between a "sexy" male trait, which may diminish fitness, and female preference for that trait. The more attractive the male trait, the more a female benefits her progeny by preferring it, since the increased attractiveness of her sons increases mating success enough to make up for their lower survival. This circumstance may give rise to runaway coevolution between male trait and female preference (Lande 1981). Ryan (p. 152) cites one instance of such coevolution but finds few others; I find that polygenic models do not easily yield the covariance of male trait with female preference needed to drive a runaway (Leigh, unpublished). Finally, males may evolve a trait exploiting a pre-existing female preference, 
such as that of female tungaras for whines with chucks, or of platyfish for males with sword-like tails. Male fritillary butterflies, moreover would prefer females that flap their wings much faster than is actually possible, just as female widow birds would prefer males with tails longer than any existing in nature (Ryan, pp. 62, 65). Similarly, many human beings enjoy "Barbie dolls" whose figures represent unrealizable extremes of "attractive" female form. I have passed over Ryan's discussion of sexual selection in human beings, which he understands far less well than frogs, fish, moths and butterflies. He often writes as if sexual selection in human beings were best studied in singles bars, although when analyzing the dangers of pornography (p. 162), he remembers that to reproduce, most human beings must form stable relationships with partners willing to cooperate in child-rearing.

Ryan's book is a balanced, clear, well-written study of factors affecting how sexual selection works. What does this tell us about the evolution of beauty? Ryan (p. 19) says that beauty is what appeals to the mind of the chooser. The view of what is beautiful, however, must be sufficiently similar among members of an interbreeding population that they mate with each other. This does little to explain why human beings find the colors, shapes and sounds of courting males of many species so beautiful (Darwin 1871, vol. 1, p. 63; Haldane 1932 p. 162).

Prum's book focuses on birds and, less extensively, human beings. He began watching and identifying birds at age 10, and learned in college, to his delight, that birdwatching suited him to study bird evolution. He has become a naturalist who really understands his birds. $\mathrm{He}$ views beauty as expressing a relation between an object and its observer. He seeks to infer a female bird's subjective reaction to the beauty of her suitors by whom she chooses to mate with. How are a male's ornaments and performances adapted to grip her with a desire to mate with him? Changeux (2012, p. 39) artist faces a similar problem: how to grip a viewer with his emotional reaction to a particular scene. Prum is inspired by Darwin's (1871) theory of sexual selection by female choice, and rightly fascinated by the great role female choice can play in evolution. He also argues, often convincingly, that females sometimes favor beauty for its own sake, even when it lowers the fitness for making a living of both signaler and chooser.

An unfortunate drone bass mars the book, which I will discuss before focusing on his book's many good qualities, for this book is one of the very few great books it has been my privilege to review. He views himself as a lone advocate of Darwin's theory of selection by female choice, facing monolithic opposition from those who assert that females use criteria that choose males with good genes (or other useful properties). Ryan's book reveals that others realize the arbitrariness of female choice. Ryan says that females can choose beauty without regard to usefulness, although he also finds abundant evidence that female criteria of beauty usually favor healthy males (how could a feeble Vogelkop bowerbird find the energy to build the huge bower females expect of him?). Ryan is no part of the implacable, monolithic opposition Prum sees himself facing. Prum's (2003) harsh attitude to the few opponents of his views on bird ancestry, moreover, sits oddly with his complaints about his own treatment.

Prum (chapter 1), however, rightly emphasizes the opposition Darwin's theory of female choice originally faced. Wallace insisted that non-human females were incapable of choice; Mivart thought the same of women! So many found the idea of female choice so revolting and so dangerous that the idea slept for a century. Only Fisher (1930) accepted the importance of female choice, despite his social conservatism and attraction to eugenics. Prum criticizes adaptationism because, like Lewontin, he finds adaptation a dangerously normative concept. He thinks that sexual selection by female choice leads to a more diverse, beautiful world. He also criticizes the population geneticists' measure of fitness as being too indiscriminate. Fisher (1930), however, an ocean-going adaptationist (and eugeneticist) whose Malthusian parameter refined the population geneticists' fitness concept, first showed how non-adaptive female preferences might evolve.

What has Prum done with Darwin's idea? First, Prum (pp. 54-63) amplifies Darwin's (1871, vol. 2, p. 92) convincing argument that the refined beauty of the male Argus pheasant's display "may serve as a charm for the female, and for no other purpose." Then he discusses manakins, small birds whose males compete to attract females by species-specific combinations of beautiful appearance, elaborate, acrobatic dances, and associated sound effects. Prum (p. 90) argues that their diversity of displays could only be driven by female choice, choosing mates on aesthetic criteria, not the goodness of their genes. He must be right: sexual selection generates far more diversity, far faster, and seemingly far more capriciously than does natural selection (West-Eberhard 1983). Then Prum (pp. 126-134) shows that the wings of male clubwinged manakins are uniquely deformed so that the males can make music with them. Female wings show correlated, but much milder deformation. Here, female choice decreases adaptedness for making a living in both chooser and chosen.

Next comes Prum's most important and original argument. When conflict arises between males trying to force females to mate with them and females defending their freedom to choose their mate, female choice can prevail. In dense populations of non-territorial 
ducks, $40 \%$ of female copulations are forced by rogue males, but males that females chose as mates sire 95-98\% of their young. In these populations, complex penises designed to fertilize the most resistant female have coevolved with equally complex vaginas designed to prevent forced fertilizations. Female choice has prevailed, at a cost: resisting forced matings often injures, and may kill, resisters. The great advantage of breeding from nonviolent males outweighs these costs. In less dense populations of territorial ducks, female choice reigns uncontested (Prum, pp. 157-174). Next, he turns to bowerbirds. The most basal court-building bowerbirds, tooth-billed bowerbirds, build no bowers but make their courts attractive by paving them with large green leaves. Females inspecting the court are easily forced to mate. Recent work shows that bowers are designed both to attract females and to protect them from forced matings. Females prefer males whose bowers they can look at without being forced to mate (Prum, pp. 194-204). Finally, most birds lack penises, thanks probably to female choice, because a female must will it for a penis-less male to fertilize her. Prum (pp. 178-180) thinks this circumstance allowed monogamy to become prevalent among birds. Female choice must be adaptive, for female reproduction is usually what limits a population's growth.

Manakin dances are ritualized contests, which Huizinga (1950, pp. 13, 76) classified as a form of play. Male manakins form leks, groups of males competing for mates, each with his own court especially prepared for his performances, because females mate only with males in leks where their performances are easily compared (Prum, pp. 209-212). Huizinga (1950, p. 47) says of ritualized contests among birds that "It is doubly remarkable that birds, phylogenetically so far removed from human beings, should have so much in common with them. Woodcocks perform dances, crows hold flying-contests, bowerbirds... decorate their" bowers. Huizinga views play-especially ritualized contest-as civilizing activities. Primitive law courts replaced violent feuds by ritualized contests (Hyams 2003), which originally served more to keep the peace than to do justice (Huizinga 1950, pp. 78-79). Similarly, by choosing males from leks, female manakins have promoted social, even cooperative, behavior among a lek's males. Males generally remain in the same lek all their lives, so leks are stable groups. Males that disrupt each other's performances cause females to choose other, more beautifully ordered, leks, Male cooperation reaches an apogee in Chiroxiphia, where a lek's five or more males join in a cooperative dance which, if successful, attracts mates for the alpha male. The hierarchy of the dance establishes who succeeds the current alpha male when he dies. The ritualized contests females favor have turned males into social animals that rely on each other's company (Prum, pp. 211-221).

Prum closes with a long discussion of sexual selection among human beings. I highlight those parts that emphasize the far-reaching importance of female choice in human evolution. Male orangutans, gorillas and chimpanzees mate with any female in estrous they meet. Human males-men-are much choosier, because for them, mating, especially repeated mating with the same woman, normally entailed commitment to help raise the resulting young (Prum, p. 235). Men, like male bonobos, mate frequently with females that are not currently fertile, only bonobos mate promiscuously to maintain troop solidarity, whereas human beings usually did so to maintain the child-rearing pair bond (Prum, pp. 231-232). In great apes, bonobos excepted, females have little choice in who mates with them. Invading males cause a third of the deaths among gorilla infants, because killing infants brings their mothers into estrous sooner (Prum, p. 287). Men almost never murder stepchildren for their own reproductive benefit: male-male violence is much diminished among human beings. Safety from murder by rogue males allows a human child a much longer period of dependence during which it can learn language and the social skills it needs, and its brain can develop its full cognitive potential (Prum, pp. 289-290). In orangutans and gorillas, male fangs (canines) are much longer than females', and adult males weigh over twice as much as females, giving males coercive power over females. Men, however, average only $16 \%$ heavier than women, their canines are not much longer than their other teeth, and they are equally long in the two sexes. All this was already true for Australopithecus 3.5 million years ago. Chimpanzees and bonobos are intermediate in these respects between the other great apes and ourselves. Prum (pp. 294-297) thinks the diminished differences in size and weaponry between men and women made it much harder for men to force matings on women, and credits these changes to female choice of less threatening males, which tended to liberate women from male sexual violence. Among other effects of mate choice by women was the evolution of monogamy in hunter-gatherer tribes, which are fiercely egalitarian (Boehm 2012). The advent of agriculture and market economies allowed economic inequality and social hierarchy to arise, which compromised female freedom to choose (Prum, pp. 331-332).

What, in the end, has Prum accomplished? He has shown that in birds, female choice drove the evolution of great beauty, time and again. Moreover, this beauty often does not help its possessors make a living: it evolved only for its own sake. Prum has exploded a great many adaptationist myths about human sexuality. Like Fisher (1930), I am an adaptationist, but I have no use for the 
adaptationist mythology that so disgusted Thompson (1942, pp. 958-961) with the evolutionary theory of his day.

No more than Ryan, however, has Prum shown how female choice can favor an aesthetics we share so extensively with birds (Darwin 1871; Huizinga 1950). I know of only two phenomena that may spread aesthetics beyond a single species. Both involve mutualisms among species where attracting partners plays a crucial role. The first is "social mimicry" (Moynihan 1968, pp. 316-317), where tropical birds that forage together in mixed-species flocks often share markings of similar color and pattern that reinforce the join-and-follow responses that cause flocking. In flocking montane tanagers these can be strikingly beautiful. The second arises among plants competing for pollinators and seed dispersers (West-Eberhard 1983, pp. 169-170). Plants attract these animals by the beauty of color, pattern, form and/or scent of their flowers and fruit. But why do human beings so often find these flowers and fruit beautiful?

Prum also argued persuasively from comparative evidence for the "civilizing" influence of female choice in suppressing male sexual violence. In birds, he has given three evolutionary series of female choice countering male coercion. What changes between chimpanzee and australopithecine ecology so favored female choice in the latter, however, is a total mystery to me. I hope future work fills this gap, for it would greatly amplify our understanding of our human heritage.

\section{Authors' contributions}

EL read the books and wrote the book review. The author read and approved the final manuscript.

\section{Competing interests}

The author declares that he has no competing interests.

\section{Publisher's Note}

Springer Nature remains neutral with regard to jurisdictional claims in published maps and institutional affiliations.

Received: 3 August 2018 Accepted: 9 August 2018

Published online: 30 August 2018

\section{References}

Boehm C. Moral origins: the evolution of virtue, altruism and shame. New York: Basic Books; 2012

Changeux J-P. The good, the true and the beautiful. Odile Jacob and New Haven: Yale University Press; 2012.

Darwin C. The descent of man, and selection in relation to sex. London: John Murray; 1871

Fabre JH. The geeat peacock. In: Fabre JH, editor. The life of the caterpillar. New York: Dodd, Mead; 1916. p. 246-76.

Fisher RA. The genetical theory of natural selection. Oxford: Oxford University Press; 1930

Haldane JBS. The causes of evolution. London: Longmans, Green and Co.; 1932.

Hardy GH. A mathematician's apology. 2nd ed. Cambridge: Cambridge University Press; 1967

Huizinga J. Homo ludens: a study of the play element of culture. New York: Roy; 1950.

Hyams PR. Rancor and reconciliation in medieval England. Ithaca NY: Cornell University Press; 2003

Lande R. Models of speciation by sexual selection on polygenic traits. PNAS. 1981:78:3721-5.

Leigh EG Jr. Genes, bees and ecosystems: the evolution of a common interest among individuals. Trends Ecol Evol. 1991;6:257-62.

Lorenz K. Behind the mirror: a search for a natural history of human knowledge. London: Methuen; 1977.

Moynihan M. Social mimicry: character convergence versis character displacement. Evolution. 1968;22:315-31.

Prum RO. Are current critiques of the theropod origin of birds science? Rebuttal to Feduccia 2002. Auk. 2003;120:550-61.

Ryan MJ. Female mate choice in a neotropical frog. Science. 1980;209:523-5.

Thompson DW. On growth and form. 2nd ed. Cambridge: Cambridge University Press; 1942

West-Eberhard MJ. Sexual selection, social competition, and speciation. Quart Rev Biol. 1983:58:155-83.

Williams GC. Adaptation and natural selection. Princeton: Princeton University Press; 1966

\footnotetext{
Ready to submit your research? Choose BMC and benefit from:

- fast, convenient online submission

- thorough peer review by experienced researchers in your field

- rapid publication on acceptance

- support for research data, including large and complex data types

- gold Open Access which fosters wider collaboration and increased citations

- maximum visibility for your research: over 100M website views per year

At $\mathrm{BMC}$, research is always in progress.

Learn more biomedcentral.com/submissions 